\title{
Poverty and Gender Relation: Developmentalism in 'Penderes dan Pengidep'
}

\author{
${ }^{1}$ AIDATUL CHUSNA, ${ }^{2}$ MUHAMMAD TAUFIQURROHMAN, ${ }^{3}$ ARIZAL MUTAHIR \\ ${ }_{1,2}$ Faculty of Humanities, Universitas Jenderal Soedirman, Purwokerto, Indonesia \\ ${ }^{3}$ Faculty of Social and Political Sciences, Universitas Jenderal Soedirman, Purwokerto, Indonesia \\ correspondence: aidatul.chusna@gmail.com
}

\begin{abstract}
Developmentalism emphasizes economic progress as an essential factor in improving social and political life. It has been implemented in Indonesia since New Order government and continued by Joko Widodo administration. However, is this ideology really able to improve the welfare of people equally? This paper aims to reveal the impact of developmentalism on rural communities through the documentary film 'Penderes dan Pengidep'. It presents the life of peasant families in Purbalingga. Textual analysis method is done by taking data from dialogues between characters, daily activities, and spaces in the house depicted in the film. Furthermore, contextual analysis was carried out by conducting in-depth interviews with peasant and employees of nira cooperative in Purbalingga. This study shows that developmentalism does not reach the poor, as represented by the characters of this film. Due to poverty, women must play a dual role in the family, as a housewife and the second income earners. This study is expected to contribute to studies that focus on the micro-level of social issues, as found in the daily life of a family. In addition, it also augments to studies of anti-developmentalism films that are still rarely conducted.
\end{abstract}

Keywords: developmentalism, farmers, documentary films

\section{Introduction}

The basic assumption of developmentalism is that economic development is needed, as economics is an essential factor to make social and political progress. This assumption has dominated third world countries as a single solution to overcome poverty in these countries. New Order can be said as the perfect model of developmentalism in Indonesia (Taufiqurrohman, et.al, 2017). The ideology was adapted and adopted by the government in a range of strategies which include economic, social, and political fields. The first is known as the floating mass policy. It prohibits the existence of mass organizations established at the level of the village. The second strategy is replacing the democratic system in the election of village leader with either a rigorous selection of candidates who have been determined by the government before or even the direct placement of government officials or military as the head of the village. The establishment of KUD (Koperasi Unit
Desa), a Village Unit Cooperative, is the third strategy in the economic field. It becomes the only cooperative institution allowed to operate in the sub-unit (village) level. Moreover, in 1979 the tradition of rembug desa (villagers' informal meeting) was eliminated and replaced by an institution established, controlled, and legalized by the government (Sasono in Fakih, 2016).

However, the programs run by the New Order government which has been in power for more than three decades has apparently not brought significant progress in Indonesia; even poverty is still a major problem in the country. The failure of the government, colored by the issues of corruption, collusion, and nepotism, ended the New Order era and became the beginning of the reform era in Indonesia in 1998. Today, under Joko Widodo administration, the so-called New Developmentalism emphasizes on industrial policy, on industry-related policy, raising Indonesia's status in the international ranking, the improvement of state owned enterprises

Received: 2020-03-28, Revised: 2020-05-05, Accepted: 2020-06-03 
as the motor of economic growth, regulating any welfare and social protection agenda funded by the state (Warburton, 2018).

Reformation has brought a new atmosphere for the Indonesian people. One of the significant changes is freedom of thought, ideas, and opinion. Indonesian people who once lived in an authoritarian and repressive government began to feel the freedom to express their thought, ideas, opinion, and even criticism to the new government concerning social, economic, and political issues. The film is one of the media to express them in public. Supported by the rapid growth of technology, especially the various innovation of more sophisticated but cheaper cameras, film is no longer owned by certain circles. Nowadays, everyone can make films.

In the Reformation era, Indonesia's film industry is not only enlivened by popular or mainstream films, but also by independent films which are rapidly increasing. These independent films are not only produced by young people from the capital or other big cities but also those who live outside Jakarta, the capital city of Indonesia. These side-stream films raised a lot of issues that happened in their respective regions. Thus, independent films become a site of criticism.

Penderes dan Pengidep is one of those side-stream films. This documentary film was produced in 2014 by a group of high schoolers who join a film making extra-curricular activity in their school named SMA Kutasari. The film received many awards at film festivals held in various regions, including Best Film in the documentary category of students of the Documentary Film Festival (FFD) Yogyakarta in 2014; the best film for short documentary category of students at the Malang Film Festival (Mafifest) 2014; Best Sound System, Best Cinematography, Best Film Idea, Best Directing, and Best Documentary Film at Madyapadma 2014; Favourite Documentary Film for 2014 Purbalingga Film Festival Viewers; 2014 Best Student Independent Film Appreciation (AFI) held by the Ministry of Education and Culture; and a documentary film nominee at the 2014 Indonesian Film Festival (FFI).

Penderes and Pengidep (2014) tell about the poor life of a rural family in Purbalingga ${ }^{1}$, a regency of Central Java of Indonesia. The regency is well-known as one of the biggest palm sugar productions in Indonesia. Penderes is the Indonesian term for peasant who harvests nira, a sap obtained from the inflorescent of palm trees, and produces palm sugar. Meanwhile, Pengidep is an Indonesian word for people who make false eyelashes (idep is a Javanese word of eyelashes). In addition to the growth of palm sugar production, Purbalingga is also famous for the wig and false eye-lashes industries. These industries provide job opportunities for local people as they need many labors for the production. As the above mentioned, the film presents the life of these two workers in a rural area of this region. However, their life story does not resonate with the bright picture of Purbalingga as the center of these industries. The documentary film portrays a different reality. The peasant presented in this film is the traditional one who has to rent palm trees to produce palm sugar. His income is unequal to the risk of falling from trees that he climbs every day. A similar story is also experienced by the home-made false eye-lashes labor in this region. The low price of palm sugar and false eyelashes they produce indirectly shows the dark side of the developmentalism in this area.

This paper is aimed at revealing the poverty of the peasant family represented in Penderes dan Pengidep documentary film as the impact of development on local life. It focuses on the discussion of poverty in Purbalingga society, especially the traditional farmer in rural areas. This condition also brings changes to the gender relations of the people affected by developmentalism.

Gender is a social and cultural construct (Hasanah and Musyafak, 2017). The traditional essentialist assumption which mentions that women are weak and entitled in the domestic works, while men are superior and responsible in public areas is still strongly held by society. In fact, this patriarchal belief has disadvantaged women (Probosiwi, 2015). The assumption led to the gender role division and socialization from the smallest unit, that is family. According to Parsons and Bale, a father has an instrumental role, which means that he's the income provider. Meanwhile, the wife has an expressive role, that is the roles of taking care of the household and the emotional bonds of the family (Flynn, 2011; Crossman, 2020) The assumption is strengthened by what Glicke and Fiske (in Overall and Hammond, 2018) called as "benevolent sexism", which gives a positive expression of women by admiring "women's traditional caregiving roles" and advising men to "cherish, protect, and provide for 
women." However, social change happens as modification results during the social process, from the formation of behavior patterns, social structure, and interaction- including changes in values, norms, and culture (Sztompka in Aisyah, 2013). It thus also changes gender relations. Social changes caused by developmentalism is a case in point.

Developmentalism is rooted from the concept of modernism, which focuses on the distinction between traditionalism and modernism (Hout, 2016). Development is seen as an evolutionary process of moving from traditionalism to modernism. Traditionalism is identical to any values, norms, and ways of life from "Third World Countries," while modernism means any progress of the West after the industrial revolution. Modernism is always considered as the only solution to the problems of a human being around the world from hunger, poverty, uneducatedness, etc.the problems of traditionalism (Fakih, 2016; Pathak \& Das, 2019).

Wallerstein (Robinson, 2011) argues that the modern world economy, or else known as the Capitalist world economy, creates a single worldwide structure based on the Market and production network. The structure divides the world into three hierarchical areas: the core, the periphery, and the semi-periphery. The core is the controlling and developed countries, while the periphery is the group of countries which are subordinated to the core through colonialism or other means. The third category, the semiperiphery, are those in fluctuating, either moving down from the core, or moving up, but also becoming "a permanent feature of the world system" (Arrighi in Dunaway \& Clelland, 2017).

Wallerstein further shows the unequal exchange of high-wage products (the manufacturing producers) and low-wage products (the raw material producer) in the relation between the core and the periphery. Meanwhile, the semi periphery has an important role in the system, as he puts it:

"The semi-pheripery...is not an artifice of statistical cutting points, nor is it a residual category. The semi-periphery is a necessary structural element in a world economy. These areas play a role parallel to that played, mutatis mutandi, by middle trading groups in an empire. They are collection points of vital skills that are often politically unpopular. These middle areas (like middle groups in an empire) partially deflect the political pressures which groups primarily located in peripheral areas might otherwise direct against core states and the groups which operate within and through their state machineries". (ibid)

Wallerstein's world system shows the hierarchical grouping of countries from the most to the least benefitted regions due to the unequal exchange in the mode of production. The core dominates the economic relationship in the system, while the rest are those being dominated. The theory thus shows that capitalism as the modern world economy brings unequal development for worldwide countries. The failure has brought to the new model of developmentalism, which focuses on middle-income countries, defends open market and growth by increasing the export of manufactured goods (Bresser-Pereira,2019)

Through the reality of traditional farmer and informal labour captured by the lens of Penderes dan Pengidep documentary film, the paper argues that developmentalism which is assumed to bring prosperity and economic growth is in fact only beneficial to the powerful parties. It even impoverishes the weak, such as small farmers and informal labor.

\section{Research Methodology}

This study utilizes both textual and contextual analysis, which is conducted in some steps: (1) formulating the issue found in the film to be researched; (2) framing relevant theories about developmentalism; (3) collecting and categorizing the primary data taken from the film and the supporting data from the newspaper, articles, and interviews; (4) analyzing the selected data using the theory of developmentalism as the theoretical framework; and (5) concluding the finding and analysis to answer the question of the study.

To investigate the issues of gender relation and poverty reflected in Penderes dan Pengidep documentary film, this paper applies a textual approach which focuses on the narrative, the characters, and the setting of the film as the primary data of the research. These data are analyzed as the evidence of how developmentalism is actually giving impacts to the society-especially the poor; how this evidence represents the what-so-called ideals of developmentalism in Indonesia. The theory of world system proposed by Immanuel Wallerstein becomes the theoretical framework to examine the impact of developmentalism in Indonesia. 
Moreover, issues of developmentalism depicted in the film are further discussed in the contextual realm. This approach is conducted by collecting other data from previous related researches, articles in mass media, and -more importantly- in-depth interviews. There are 5 informants being interviewed; they are a representative of Nira cooperatives and two employees of labor office of Purbalingga regency who deal with labor force in this area, as the primary source; while a traditional Nira farmer and a female false eye-lashes home worker as the secondary source. Those informants are chosen with the consideration that they represent the subject of the case study. The data resulted give relevant on valuable information about traditional nira farmer and home labor of false eye-lashes production from the perspective of the workers themselves, the cooperatives as the collector assigned by the local government, and the local government who is responsible in protecting labor force.

\section{Results and Discussion}

\section{Poverty and Gender Relation in Pen- deres dan Pengidep (2014)}

Penderes Dan Pengidep is a non-fiction film which captures the day-to-day life of a rural family in Purbalingga. The film focuses on parents who are struggling against the family's financial problem (Ulfi, 2014). The father of the family, Suwitno, works as penderes $^{1}$, or a nira peasant. Nira is a sap obtained by tapping the inflorescences of various palm trees. Every morning and evening, Suwitno climbs coconut trees to take the sap which is then processed into palm sugar. Meanwhile, Suwini, the mother, works as pengidep, a person who makes false eyelashes. She does her work every night, after helping her husband processing the sap into palm sugar. Her work lasts for hours, from night to dawn.

With an observational model, without the presence of narrators or music throughout the film, Penderes dan Pengidep is able to capture the reality of the family's life as it is. The most dominant reality portrayed by this film is poverty. The financial problems experienced by Suwitno's family have been stated since the beginning, as the film opens with a brief note as follows:

Disela kesibukan sebagai ibu rumah tangga, Suwini, ibu tiga anak, menyempatkan ngidep (membuat bulu mata). Sementara Suwitno, suaminya, sehari dua kali, pagi dan sore, harus naik-turun 21 pohon kelapa yang disewa untuk mengambil air nira. Harga gula jawa tak semanis rasa gulanya.

["On the sideline of her role as a housewife, Suwini, a mother of three children, used her time to make false eyelashes. While Suwitno, her husband, two times a day, in the morning and evening, had to go up and down twentyone coconut trees that he had hired to take the juice of nira. The price is not as sweet as the sugar']

The last sentence 'Harga gula jawa tak semanis rasa gulanya (the sugar price is not as sweet as the sugar itself)' is an irony which describes the poor condition of Nira farmers in Purbalingga. The regency becomes one of the biggest producers of palm sugar in Indonesia. However, the success of palm sugar production in this region is not followed by the prosperity of the farmers who produce it.

The poor condition of nira farmers in Purbalingga is represented by Suwitno in this film. The house of the poor family became the main setting of this film, in addition to the coconut plantation rented by Suwitno. Figure 1 below shows the poor condition of the house:

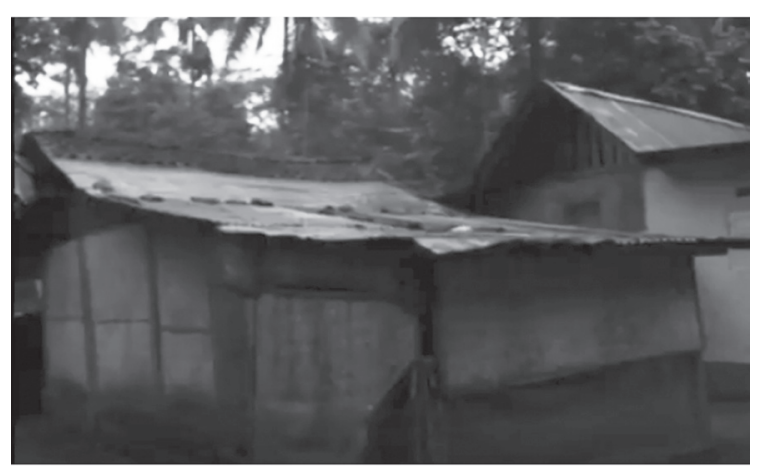

Figure 1. Suwitno's house

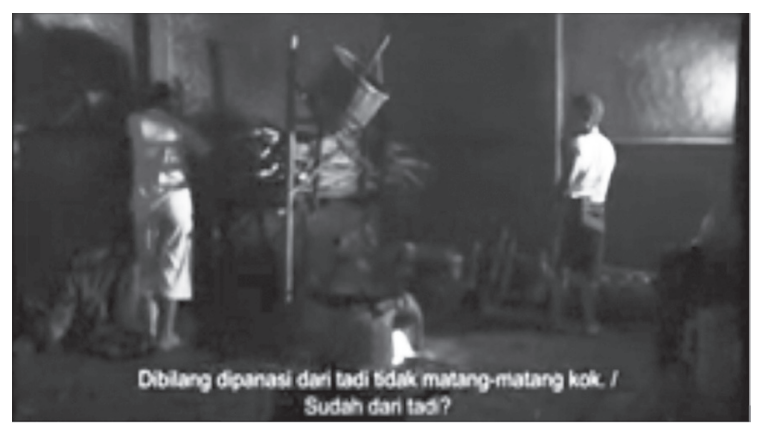

Figure 2. The kitchen where Suwitno and Suwini produce palm sugar traditionally

There are two rooms that are the main settings of this documentary film, mainly the kitchen and living room. The kitchen room, 
or Pawon in Javanese, becomes a significant space in uncovering the problem of poverty in this family - from processing the sap into brown sugar using very simple tools, such as the use of traditional stoves and firewood and sugar molds from bamboo, as seen in figure 2 and figure 3.

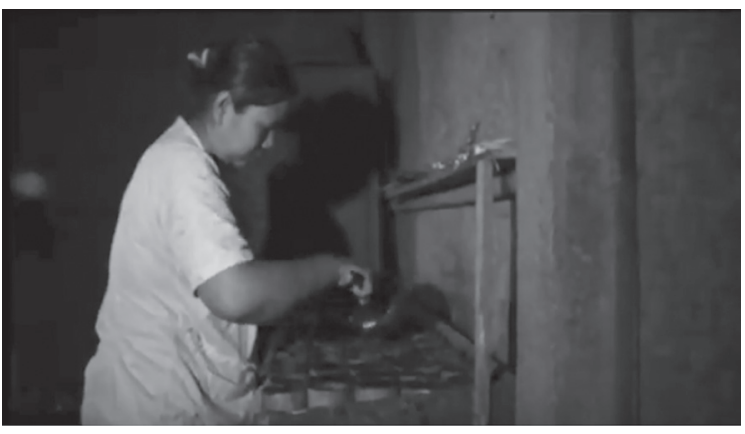

Figure 3. Suwini is pouring cooked nira into sugar molds made from bamboo

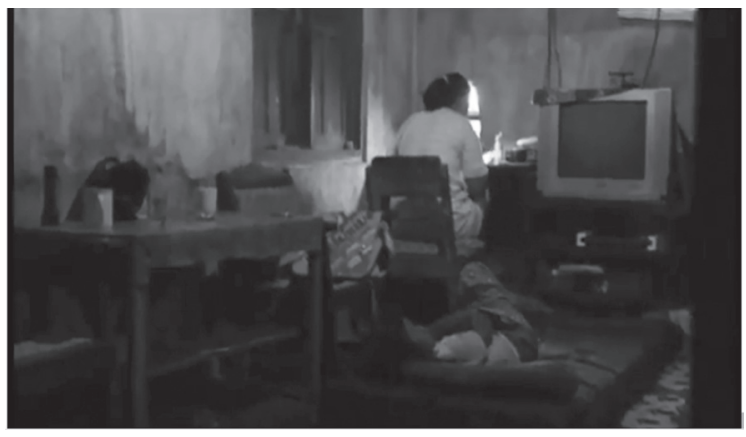

Figure 4. The living room; most activities are conducted in this place

Moreover, the lens of the film also captures the condition of the living room. For this family, this small room as shown in figure 4 has multifunctions: as a place to eat, to watch television, to sleep for their daughter. Also, the corner of the room is used by Suwarni to make false eyelashes all day long, as shown in figure 5.

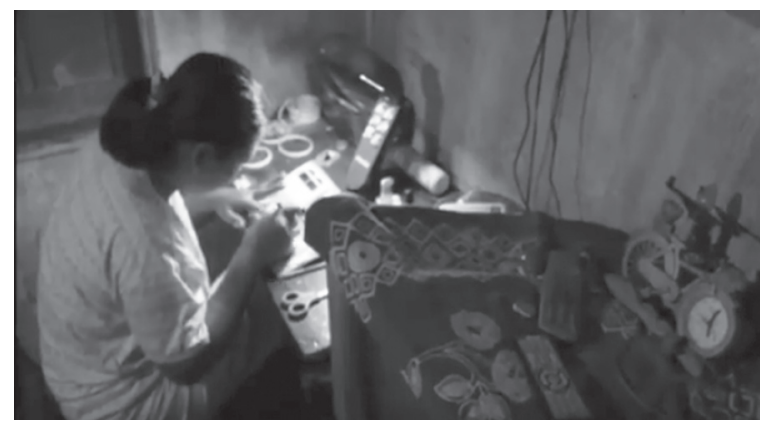

Figure 5. The corner of the living room, where Suwini is making false eye-lashes for hours
The conversations between Suwitno and his wife Suwini show the serious financial problem that this family is dealing with. The dialogue centers on the daily need of the family and the financial problem they are facing due to the low price of the palm sugar they sell. A brief dialogue between the two was dominated by complaints raised by Suwini regarding the family's financial difficulties.

Suwini: .... Jatah sembako (beras raskin) ya tidak datang-datang. Padahal mau kondangan dan lainnya. Apa lagi buat membantu korban banjir ya? Sudah berapa bulan tidak datang. Apa sudah tidak ada jatah sembako ya? Biasanya bila Desember tidak datang, diganti Januari.

Suwitno: Ini (Suwito memberi uang ke Suwini) Suwini: Buat bayar hutang sana sini. Saya cuma kebagian Rp 2 ribu? Uang yang disini juga sudah diambil Juli lagi. Jadi berapa kilogram gulanya?

Suwitno: $10 \mathrm{~kg}$

Suwini: Berarti 1 kg nya Rp 6.200 ya? Naik 200. Saya buat arisan saja belum ada ya. (Suwitno meninggalkan ruang dapur) Bingung ya jadi orang susah.

[Suwini: ... (the subsidized rice is not coming yet; whereas I need it for kondangan. Is it used for flood victims? It does not come for months. Is the program withdrawn? It's usually distributed in December. It is now distributed in January.)

Suwitno: Here. (Suwito is giving money from selling palm sugar to Suwini)

Suwini: I'll use it to pay debts. Only two thousand rupiahs left? The money here has also been taken by Juli. So how many kilograms of sugar did you sell?

Suwitno: 10 kilos

Suwini: Does that mean 1 kilo is 6,200 rupiah? The price increases 200 rupiahs. There's no more money for arisan (gathering). (Suwitno leaves the kitchen).]

The above dialogue clearly reveals the family's economic difficulties. Raskin ${ }^{2}$ from the government is the solution to fulfill the family's needs. In addition, the money gets from selling the sugar is not able to cover household needs. The dialogue between Suwini and a mortgagee below also provides evidence on the financial problem of the family.

Suwini: Hari ini saya libur setor, gimana Mas? Tukang kredit: Diisi separo sajalah.

Suwini: Tidak ada kok ...yakin.

Debt Collector: Sedang tutup buku soalnya. Saya juga pusing sekali. Penjual Kerupuk libur lagi. Tadi saya habis bertengkar dengannya.

Suwini: Saya sungguh sedang tidak punya uang satu rupiah pun

Tukang kreditr: Haduh... harapan terakhir tinggal ibu.

Suwini: Kalau ada si sudah aku kasih meski Cuma separoh. Tapi bener, lagi tidak punya uang. Saya memang tidak setiap hari menjual gula. Tapi memang tidak sedang punya uang. Ini saja buat jajan anak-anak sudah tidak punya uang.

[Suwini: Today I have no money to deposit, Sir. 
Mortgagee: Just fill in half

Suwini: Nothing really ... sure.

Mortgagee: It's the closing process. I don't know what else to do. The crackers seller was off again. I had had a fight with him earlier.

Suwini: I really don't have any money

Mortgagee: Gosh ... you're my last hope, mom. Suwini: If there is one, I have already given even though it's only half. But really, I don't have money. I do not sell sugar every day. But, indeed, I do not have money. This is just for kids snacks already do not have money.] Again, the dialogue between Suwini and a mortgagee above shows the poor condition of the family. The debt becomes another problem that the family has to deal with.

Penderes dan Pengidep shows the significant role of Suwini in taking care of the household. As the film captures the daily life of the family, Suwini is seen as her chores as a housewife from the earliest morning to the next morning tirelessly. Furthermore, Suwini also takes part in the making of palm sugar from the Nira sap that her husband takes every morning and evening. However, the money that they get from selling palm sugar cannot fulfill the family's daily needs. Thus, Suwini shares responsibility as the income-earner by becoming home labor.

At night, after completing all the household chores, Suwini begins her work as a pengidep. She chooses to work at home as she also has another responsibility to take care of the household and the children. Her conversation with her youngest child explains her decision to work at home rather than in a factory.

Suwini: Jam segini belumdapat sedikitpun. Besok tidak bisa setor. Nanti bisa dimarahi.

The child: Kerja di PT saja, Ma.

Suwini: Kalau Mama kerja di PT, kamu sama siapa di rumah?

The child: Saya ikut Mama kerja. Saya dan Ipah.

Suwini: Tapi kalau di PT jangan rewel ya? The child: Iya, tapi nanti saya jajan.

Suwini: Ya, jangan jajan terus, nanti uang Mama habis. Sama saja kerja untuk jajan.

The above conversation implies Suwini's dual responsibilities which she cannot leave behind- taking care of the children and earning income by making false eye lashes.

\section{Poverty and Developmentalism: Purbalingga in Paradox}

Industrialization is considered a marker of an area is in the process of modernization. Developmentalism is meant to modernize a region. Thus, the growth of industries and the increasing flow of foreign capital in Purbalingga is destined for the economic growth of the region. The economic growth of an area means an increase in the welfare of its people; however, the question then arises: is economic growth experienced by Purbalingga society in all levels or classes.
The increasing amount of palm sugar production has made Purbalingga one of the largest palm sugar industries in Indonesia (Sahat, 2017: 8). The crystal palm sugar has been exported to various countries of Asian, American, and European areas. Even the demand for crystal palm sugar continues to increase in Japan's market. For this reason, the local government provides assistance in the form of equipment and training for the production of crystal palm sugar to the farmers.

Nevertheless, the growth of palm sugar production is not in resonance with the welfare of the producers, especially the traditional ones such as Suwitno. As a traditional/homemade palm sugar producer, Suwitno does not have the power to determine the selling price of the sugar according to the production cost that he has spent. The prices determined by the collectors are very low, even though market prices are increasing along with the increasing demand. In addition, traditional palm sugar production is unable to compete with the production of crystal palm sugar, which is able to enter the international market. Crystal palm sugar is produced with modern machinery and skills that they don't have. This shows how technological developments affect the life of traditional farmers. International market-oriented technological advancements cannot be reached by small farmers such as Suwitno due to the lack of capital or expertise. Also, it proves that poverty isn't only about the shortage of food and productive asset, but also the limited participation in public activities and development (Sukesi, 2019).

Suwitno, who sells palm sugar to collectors, is helpless at the price determined by the collectors. This trading system is known as Sistem Ijon ${ }^{3}$. For traditional peasants like Suwitno, their dependence on collectors are hard to avoid. Peasant and collector build a patron-client relation based on debt and receivable accounts. The peasant is bound to the collector who provides money and services for the peasant to survive (Fuad, et.al., 2015).

Cooperative is one of the solutions founded by the local government as an effort to protect the sap farmers and home-made sugar producers. However, an employee of the cooperative mentions that this effort is still facing an obstacle. It was mentioned that not all farmers and collectors were interested in selling palm sugar products to cooperatives and choose to sell their sugar directly to the buyers who offered higher prices. He argues 
that these farmers and collectors break the agreement with the cooperative due to their lack of knowledge and the collectors' mindset of ijon practice. They haven't realized that the advantages that the cooperatives get from selling their sugar to companies will be for their benefits too. Thus, building coordination with the collectors become a solution that the cooperative takes to manage the standard price of palm sugar.

Cooperative is not only established to regulate the sale and purchase of palm sugar but also aimed at providing social insurance for the safety of the farmers. Accidents often happen to farmers when they are climbing the coconut trees to take the sap. By November 2017 in Banyumas regency, there were 129 cases that cause the farmers' physical disability and fatality (Palupi, 2017).

Postulated in the first article in Law no 40 of 2004 that all workers in Indonesia must partake in the Employment Social Security scheme managed by BPJS. These include both the salaried workers and the non-salaried workers (Setiyono \& Chalmers, 2018). Thus, the protection of farmers is one of the main concerns of the cooperative. By coordinating with BPJS (Badan Penyelenggara Jaminan Sosial- Agency for Administering Social Security) who provides the social security and protection program, Cooperative helps nira farmers to get compensation for work accidents that happen to him. However, there are still many small farmers like Suwito, who are the non-salaried workers, do not get access to this service. It happens as these farmers are not enlisted as the member of the cooperative and the lacked coordination between the cooperative and the collectors to whom they sell their palm sugar (Interview with the head of Koperasi Nira Perwira, August 8, 2018).

A similar condition is also experienced by home made false eyelashes such as Suwarni. As informal labor, Suwarni does not have social security as she doesn't work for certain companies. The false eyelashes that she produces are sold directly to a collector. The collector is the one who decides the price, which is generally low. The money that Suwarni makes from her false eyelashes production, in the end, does not help the family's economic problem much. This poor condition is certainly very contrary to the growth of the false eyelash industry that has entered the global market. Purbalingga is known as a global producer of false eyelashes and wig, it is even known as the second largest industry in the world after China. According to Tasdi, the regent of Purbalingga, this industry has absorbed up to sixty thousand workers, who are mostly women (Muzakki 2018). This industry has helped to improve the economy of the Purbalingga community, but low wages have remained the major problem until now.

The growth of palm sugar production and false eye-lashes industries in Purbaligga, along with its effects on the parties involved, prove the unequal development within capitalist system. Traditional farmers and informal labours are not able to adjust with the changes in the mode of production. Capitalist mode of production puts the homemade palm sugar and false eyelashes producers in Purbalingga in poverty, while the bigger actors (the bigger companies) are gaining more profits from the growing market of the commodities. The Paradox which happened in Purbaligga describes the paradox of developmentalism itself, that the ideology is meant for economic progress as the characteristics of natural forces and for challenges to market-led progress without government intervention. However, the progress does not give similar impact to different social groups (Bugra, 2017).

\section{Gender Relation in Traditional Peasant Family}

The two main characters of Penderes dan Pengidep are the husband and the wife. The main focus of this documentary film is how the spouse struggles to overcome the poverty of the family. As husband and wife, Suwito and Suwini have roles that are still based on the division of public and private spaces, or internal and external work. However, this division is not stiff, as both are still helping each other in doing their responsibilities.

Suwini, as a wife, works mainly in domestic space, such as cooking, cleaning houses, and caring for children, but still involves in helping her husband's productive role as palm sugar producer. Meanwhile, Suwito as a husband, along with his role as the breadwinner of the family, is also being supportive to his wife's role. The scene of Suwitno repairing his son's broken bicycle in the yard and cooking fried rice represent Suwitno's role in domestic area. The partner shows how gender role division may somewhat shaky. However, Suwini represents women with traditional gender ideology, who believe that doing "a larger share of the housework" 
is "their female identity" (Carriero \& Todesco, 2018); thus, home "is assumed to be in charge of women" (Cerrato and Cifre, 2018).

Gender role division is associated to patriarchal system in society. Patriarchy is frequently taken as 'an inherent element of the human condition across times and space, hence ahistorical' (Icaza and Vazquez, 2016). In capitalist development era, which is assumed to change the traditional society to modern era, patriarchy remains attached to society regardless the changes occur. Werlhof (as cited in Icaza and Vazquez 2016) argues that "patriarchy has been known to reach back for at least 5,000-7,000 years...Capitalism has old and far-reaching patriarchal roots; capitalism is, in fact, patriarchy's latest expression. In this sense, capitalism and patriarchy belong together".

The patriarchal based gender relation is not only present in the role differentiation but also symbolized in many ways. Room division is a case in point. Many previous studies have linked the Javanese house order as a symbol of differences in social roles between men and women (gender). The Javanese house, according to Santosa (as cited in Newberry 2013), consists of two parts, the first part of the space 'which is broader, brighter, more open, free to enter, public, and male-dominated', while the second part is a 'narrower, darker, protected, closed, private, not free to enter, and related to women'. Keeler (ibid.) added that the division of space in Javanese houses based on gender roles is associated with jromah or inner space with the womb, which symbolizes 'the frugal nature of women, and household finances show similarities with jromah and uterine links.

In Javanese culture, the kitchen is one of the main parts of a house. Similarly, the kitchen is part of the inner space that is most dominantly reflected in Penderes dan Pengidep documentary film. It shows the important role of Suwini in taking care of the family. Cooking, taking care of children, and managing household finances are reproductive roles that are identical to the role of a wife. On the other hand, Suwitno has a productive role, which is identical to work outside the home. However, Suwini runs on these two roles; her role is not limited to reproductive roles but also carries out a productive role in the household. In addition to working to take care of the household, Suwini takes what James C. Scott named a "subsistence alternative" to survive in the family hardships by becoming informal labour (Laksono, 2017). The choice of Suwini to work at home, not in a false eyelashes' factory, shows that the work she does is a side job to help her husband as the one who is assigned the main role of earning a living.

Thus, the double role that Suwini performs shows that gender role is not fixed. Developmentalism excludes poor people such as sap farmers and home sugar producers such as Suwitno. Even this poverty affects the role of the wife in the household. The wife has a dual role of taking care the family and of becoming the breadwinner with her husband. Becoming a home-made false eyelash maker is the best solution for this condition. However, like home sugar producer, homemade false eyelashes worker such as Suwini is powerless at the low prices determined by the collectors.

The powerless condition experienced by Suwini as informal labour represents the marginalization of women workers in developmentalism. Socio-economic and political factors cause this unequal treatment toward women (Probosiwi, 2015). Wig and false eyelashes industries in Purbalingga prefer recruiting women labour to men labour. Gender construction which attributes women as more patient and precise than men become the main consideration that women would make better products. At one point, the preference gives an opportunity for women to participate in productive roles. At another point, however, their works are less appreciated by the industries, proven by the low wages they receive. Suwini and other women labour of wig and eyelashes industries are unable to change their condition as they really need the job to support their family. The fear of losing the job makes them unwilling to fight for a proper salary. Thus, as Leksono argues that the preference of women labour is purportedly to prevent protests that possibly conducted by workers to demand higher wages (Chusna, et.al, 2017).

The cheap labour of Purbalingga multinational industries reflects the process of commodification in capitalist society. As everything becomes a commodity, labor force is the first commodified. The process works along with the process of capital accumulation (Bresser-Pereira, 2017). Prior to the setting of a minimum wage in 2016, the local minimum wages were based on local economic conditions and the Decent Living Needs Index (Manning and Pratomo, 2018). 
However, these wage policies seem to exclude the existence of informal labour as Suwini. The female informal worker is the most vulnerable group, referring to the dimensions of exclusion of the workforce, namely: "income groups (higher lower strata); education (tertiary secondary primary); area of residence (urban-rural); formality of employment (formal informal); gender (male female); and persons with disability" (Tadjoeddin, 2019). This dimension measures the extent of exclusion of the workforce which also brings the inequality in wage-earning.

Moreover, social protection is another exclusion to female informal workers. Local government does not provide special protection and insurance for the informal labours of eyelashes production since these labours. Unlike formal workers, these informal labours are not bound by working hours; they are working at home as they please while taking care of the household, and other obligations (interview with the Head of Industrial Affairs and Social Insurance, Labor office of Purbalingga, August 7, 2018). Thus, the case of Suwini portrays the irony behind the success story of industrialization in Purbalingga.

\section{Conclusions}

The poverty suffered by traditional farmers as depicted by the documentary film of Penderes dan Pengidep shows that developmentalism does not favor lower class society. Developmentalism which is characterized by industrialization does not provide access and opportunities for the lower classes to improve their standard of living. Instead, the developmentalism agenda only sided with certain groups of people who control the modes of production that increasingly ensnared the poor.

\section{Acknowledgment}

We would like to thank the Institute for Research and Community Service of Universitas Jenderal Soedirman for the institutional dan financial support in conducting and completing the research.

\section{Notes}

1 Purbalingga is a regency located in the southwestern part of Central Java Province in Indonesia.
2 Penderes is the Javanese term for a person whose work is taking coconut sap as the main ingredient to make palm sugar

3 Pengidep is the Javanese term for a person who makes false eyelashes. The word idep means eyelashes.

4 Raskin is the government's program aimed at strengthening food security for poor households. Started in 1998 when the monetary crisis hit Indonesia, the program is now part of the social protection program. (http://www.bulog. co.id/sekilas_raskin.php)

5 Sistem Ijon is a system by which a peasant mortgages the crop (for money) before it is harvested. (Stevens and SchimdgellTellings, 377).

\section{References}

Aisyah, N. (2013). "Relasi Gender Dalam Institusi Keluarga (Pandangan Teori Sosial Dan Feminis)". Jurnal Muwazah, 5(2), pp.203-224.

Bresser-Pereira, L.C (2019): "From classical developmentalism and postKeynesian macroeconomics to new developmentalism", Brazilian Journal of Political Economy, 39(2), 187-210. http:// dx.doi.org/10.1590/0101-315720192966

Bresser-Pereira, L. C. (2017): "The Two Forms of Capitalism: Developmentalism And Economic Liberalism", Brazilian Journal of Political Economy, 37(4), 680-703.

Bugra, A. (2017): "Two Lives of Developmentalism: A Polanyian iew from Turkey", Development as a Battlefield, International Development Policy Series No. 8, 61-80. Boston: Graduate Institute Publication http://journals.openedition. org/poldev/2306. DOI: 10.4000/ poldev. 2306

Carriero, R., \& Todesco, L. (2018): "Housework division and gender ideology When do attitudes really matter?", Demographic Research, 39, 1039-1064, https://www. jstor.org/stable/26585360

Cerrato, J., \& Cifre, E. (2018): "Gender Inequality in Household Chores and Work-Family Conflict", Frontiers in Psychology, vol.9. https:// doi.org/10.3389/fpsyg.2018.01330 Retrieved from https://www.frontiersin. org/articles/10.3389/fpsyg.2018.01330/ full

Chusna, A., Taufiqurrohman, M., \& Fatmawati, L.S.W.A. (2017): "Gender Role in Rural Life: An Audience Reception Analysis On 
Banyumas Films in Reformation Era", Lingua Cultura, 11(2), 115-119, https:// journal.binus.ac.id/index.php/Lingua/ article/view/1818/3216 DOI: 10.21512/ Ic. v11i2.1818

Crossman, A. (2020, February 11). Expressive Roles and Task Roles. Retrieved from https://www.thoughtco.com/expressiveroles-definition-3026318

Dunaway, W.A., \& Clelland, D.A. (2017): "Moving toward Theory for the $21^{\text {st }}$ Century: The Centrality of Nonwestern Semiperipheries to World Ethnic/Racial Inequality," Journal of World-Systems Research, 23(2), 400-464, https:// jwsr.pitt.edu/ojs/index.php/jwsr/article/ view/598. DOI 10.5195/JWSR.2017.598.

Fakih, M. (2016): Analisis Gender dan Transformasi Sosial, Yogyakarta: INSIST Press.

Flynn, S.I. (2011): "Family Gender Roles", Sociology Reference Guide: Gender Roles and Equality,. 64-76. California: Salem Press

Fuad, I.Z., Aenurofik, A. \& Rosyid, A. (2015): "Belenggu Tengkulak Atas Petani Pembudidaya Lele: Relasi Patron-Klien Budidaya Lele di Wonotunggal Jawa Tengah", Jurnal Hukum Islam (JHI), 13(2), 88-98, http:// e-journal.stain-pekalongan.ac.id/index. $\mathrm{php} / \mathrm{jhi}$

Hasanah, U., \& Musyafak, N. (2017). "Gender and Politics: Keterlibatan Perempuan dalam Pembangunan Politik", Sawwa, 12(3), http://journal.walisongo.ac.id/ index.php/sawwa/article/view/2080

Hout, W. (2016): "Classical approaches to development: Modernisation and dependency", Jean Grugel and Daniel Hammett (eds): The Palgrave Handbook of International Development, Basingstoke: Palgrave Macmillan, 21-39.

Icaza, R., \& Vazquez, R. (2016): "The Coloniality of Gender as a Radical Critique of Developmentalism," Wendy Harcourt (ed.): The Palgrave Handbook of Gender and Development, New York: Palgrave Macmillan, 62-73.

Laksono, P. (2017) : "Feminisasi Kemiskinan (Studi Kualitatif pada Perempuan miskin di Desa Kembang Belor Kecamatan Pacet Kabupaten Mojokerto", Habitus: Jurnal Pendidikan, Sosiologi, dan Antropologi, 1(1), 1-15, https://jurnal.uns.ac.id/ habitus/article/viewFile/18844/14950

Manning, C., \& Pratomo, D. (2018): "Labour Market Developments in the Jokowi Years",
Journal of Southeast Asian Economies, 35(2), 165-184, https://www.jstor.org/ stable/10.2307/26539212

Muzakki, K. (2018) : "Ternyata Industri Rambut Palsu Terbesar Kedua di Dunia Ada di Purbalingga." http://jateng.tribunnews. com/2018/01/20/ternyata-industrirambut-palsu-terbesar-kedua-di-duniaada-di-purbalingga.

Newberry, J. (2013): Back Door Java: Negara, Rumah Tangga, dan kampung di Keluarga Jawa, Jakarta: KITLV dan Yayasan Pustaka Obor Indonesia

Overall, N.C. \& Hammond, M.D. (2018): "How Intimate Relationships Contribute to Gender Inequality: Sexist Attitudes Encourage Women to Trade-Off Career Success for Relationship Security", Policy Insights from the Behavioral and Brain Sciences (PIBBS), 5(1), 4048, https://journals.sagepub.com/doi/ pdf/10.1177/2372732217745096

Palupi, Y. (2017): "Penderes, "Satelitpost.com, 23 November 2017: https://satelitpost. $\mathrm{com} / \mathrm{regional} /$ penderes, (accessed 04/07/19).

Pathak, D.N. \& Das, A.K. (2019): "Introduction: Developmentalism-On a Trope of (Dis)Enchantment", Investigating Developmentalism, Switzerland: Palgrave Macmillan.

Probosiwi, R. (2015): "Perempuan dan Perannya dalam Pembangunan Kesejahteraan Sosial", Natapraja, 3(1), 41-56.

Robinson, W.I. (2011): "Globalization and the sociology of Immanuel Wallerstein: A critical appraisal". International Sociology, pp.1-23. Retrieved from https://www. academia.edu/4161686/Globalization and_the_sociology_of_Immanuel_ Wallerstein_A_critical_appraisal. (Accessed 04/08/19)

Sahat, S.F. (2017): "Peluang Ekspor Gula Semut", Warta Ekspor, June Ed., retrieved from http://djpen.kemendag. go.id/app_frontend/admin/docs/ publication/9501519022481.pdf

Setiyono, B., \& Chalmers, I. (2018): "Labour Protection Policy in a Third World Economy: the Case of Indonesia", Development and Society, 47(1), 139-158, https://www. jstor.org/stable/10.2307/90020485

Stevens, A.M. \& Schimdgell-Tellings, A.E. (2004): A Comprehensive IndonesianEnglish Dictionary, Ohio: OUP

Sukesi, K., \& Inggrida, J.A. (2019): "The Changes of Economic Structure and Poverty of Women Migrant Worker in 
Majangtengah", Mimbar, 35(2), 360-370, https://ejournal.unisba.ac.id/index.php/ mimbar/article/view/4899

Tadjoeddin, M.Z. (2019): "Inequality and Exclusion in Indonesia", Journal of Southeast Asian Economies, 36(3), 284-303, https://www.jstor.org/ stable/10.2307/26842377.

Taufiqurrohman, M., Chusna, A., \& Fatmawati, L.S.W.A. (2017): "The Genealogy of Banyumas Film: From Street to Screen", Rupkatha Journal on Interdisciplinary Studies in Humanities, IX(4), 144-159.
http://rupkatha.com/V9/n4/v9n414. pdf DOI: https://dx.doi.org/10.21659/ rupkatha.v9n4.14.

Ulfi, A. (2014): Penderes dan Pengidep, Purbalingga: Papringan Pictures.

Warburton, E. (2018): "A New Developmentalism in Indonesia?", Journal of Southeast Asian Economies, 35: 3, 355-368, DOI: 10.1355/ae35-3c, retrieved from https://www.jstor.org/ stable/pdf/26545318.pdf?refreqid =exce Isior\%3Aceb781fc2b2538eac53ec8203e $8 \mathrm{df5} \mathrm{a} 4$ 